Article

\title{
Biochar as Additive in Biogas-Production from Bio-Waste
}

\author{
Daniel Meyer-Kohlstock *, Thomas Haupt, Erik Heldt, Nils Heldt and Eckhard Kraft \\ Biotechnology in Resources Management, Bauhaus-Universität Weimar, Coudraystr. 7, Weimar 99423, Germany; \\ thomas.haupt@uni-weimar.de (T.H.); erik.heldt@gmx.de (E.H.); nils.heldt@gmx.de (N.H.); \\ eckhard.kraft@uni-weimar.de (E.K.) \\ * Correspondence: meyer-kohlstock@gmx.de; Tel.: +49-3643-584630; Fax: +49-3643-584639
}

Academic Editor: Filippo Sgroi

Received: 26 January 2016; Accepted: 23 March 2016; Published: 29 March 2016

\begin{abstract}
Previous publications about biochar in anaerobic digestion show encouraging results with regard to increased biogas yields. This work investigates such effects in a solid-state fermentation of bio-waste. Unlike in previous trials, the influence of biochar is tested with a setup that simulates an industrial-scale biogas plant. Both the biogas and the methane yield increased around $5 \%$ with a biochar addition of 5\% - based on organic dry matter biochar to bio-waste. An addition of 10\% increased the yield by around $3 \%$. While scaling effects prohibit a simple transfer of the results to industrial-scale plants, and although the certainty of the results is reduced by the heterogeneity of the bio-waste, further research in this direction seems promising.
\end{abstract}

Keywords: biochar; bio-waste; biogas; anaerobic digestion; solid-state fermentation; composting

\section{Introduction}

In 2014, Germany had 8726 biogas plants with a combined electric capacity of $3905 \mathrm{MW}_{e l}$ [1]. Although this corresponds to only $4.3 \%$ of the total renewable capacity [2], these plants play a vital role as base load provider within the mix of electricity. Therefore, an additive that could increase their yields would be important for a transition to renewable energies.

Biochar is pyrolysed biomass intended for soil improvement, though its use in numerous preceding processes, e.g., as feed supplement or silage additive, is possible [3]. Because of its inert and hydrophobic nature, the surface of fresh biochar has no tendency to interact with microorganisms, nutrients, or water, the main features of this soil improver. While this changes gradually over time within the soil, this process can be accelerated by a pre-treatment through adding it as co-substrate to composting $[4,5]$. Side benefits of this addition can be the reduction of nitrogen and carbon losses, as well as the acceleration of the composting process itself [6-11].

Another option to pre-treat fresh biochar would be its addition to anaerobic digestion. While no investigation was done yet how this influences the agronomic properties of the resulting biochar-enhanced digestate, it was investigated how it influences the biogas production. Several authors have done laboratory trials to determine effects on the methane yield-the main combustible component of biogas-and the results ranged from $-8 \%$ up to $+31 \%$ [12-17]. A detailed overview including the results from this paper are provided in Section 3 Discussion.

In Germany, both pre-treatment options for biochar could often be realized at the same location. This is due to two facts. First, the German Renewable Energy Act (EEG) sets a favorable feed-in tariff for electricity from bio-waste, respectively the organic fraction of municipal solid waste (OFMSW), which is currently at 15.26 eurocent $/ \mathrm{kWh}$ for a rated power up to $500 \mathrm{~kW}$ and 13.38 eurocent $/ \mathrm{kWh}$ up to $20 \mathrm{MW}$ [18]. Second, the EEG requires in the same article that the resulting digestate has to be 
processed into compost at a facility directly connected to the biogas plant. Therefore, these plants are usually part of an earlier established composting facility.

The first biogas plants for bio-waste were installed in Germany in the 1990s. The steady addition of new plants gained more speed at the end of the 2000s, which can be attributed to new municipal initiatives in terms of energy and climate policies, as well as to revisions of the EEG favoring such facilities. In 2014 there were 75 bio-waste-to-biogas plants with annual inputs over $5000 \mathrm{Mg}$ in operation. Together they digest $1900 \mathrm{Mg}$ bio-waste per year, which is only around one third of the available bio-waste suitable for such a treatment. In terms of energy, they provide a capacity of $52 \mathrm{MW}_{e l}$ and six facilities feed biogas into a gas grid. [19] While this seems low compared to the overall biogas capacity, it plays a vital role in the waste management efforts to recover energy.

Against this background, it seemed worthwhile to investigate for the first time the influence of biochar on the anaerobic digestion of bio-waste. To raise the investigations significance for industry, the laboratory trial simulated the operations of a bio-waste-to-biogas plant in Erfurt, Germany (see Section 4 Materials and Methods). The trial results, which show a slight increase in the methane yields, lead to two conclusions. First, biochar can be pre-treated in a bio-waste-to-biogas operation, without disrupting the anaerobic digestion. Second, further investigations are necessary to determine optimal biochar qualities and rates for higher yields, as well as the effects on the subsequent composting process, including the effects on the agronomic qualities of the final compost.

\section{Results}

The trials with biochar in solid-state fermentation of bio-waste show a small increase in biogas and methane yields. Figure 1 reflects the cumulative yields over time for all three triplicates (biochar addition of $0 \%, 5 \%$, and $10 \%$ ). The curves show a typical progress in anaerobic digestion, beginning with $\mathrm{CO}_{2}$-rich biogas, slowly increasing methane production, to later crossing the reverse point of a short exponential growth and to finally reaching the plateau phase with very low methane production. In addition to the observation that the triplicates show only small yield variations, the progress of the yields is also very similar.

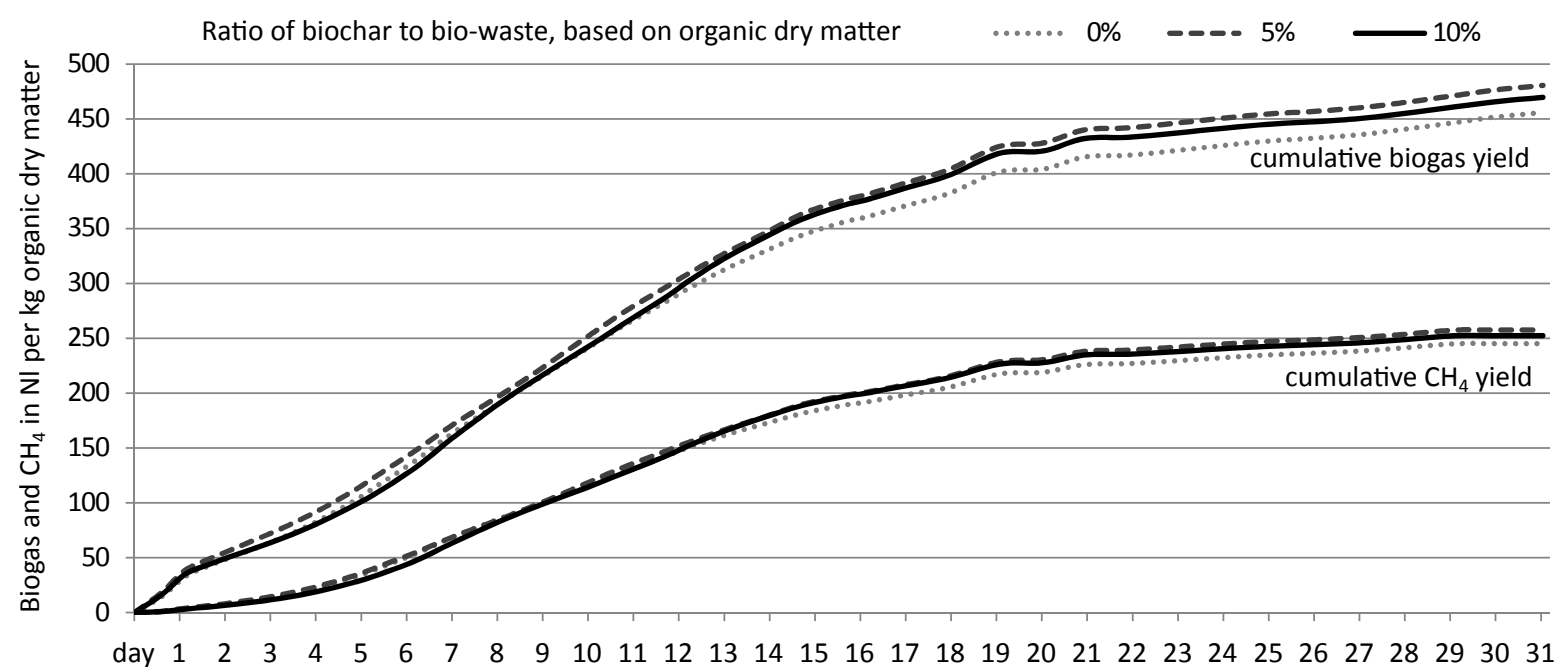

Figure 1. Cumulative biogas and methane $\left(\mathrm{CH}_{4}\right)$ yields; mean averages.

Table 1 provides the conversion of the reactor yields on day 30 into yields per kg organic dry matter (ODM), which are also visualized in Figure 2. This is done by dividing the total yields by the ODM of bio-waste, digestate and percolate in one reactor (see Section 4.2 Trial Substrates). The ODM of the biochar is not included, since it is considered to be not digestible within the trial duration. 
Table 1. Biogas and methane $\left(\mathrm{CH}_{4}\right)$ yields in total and per organic dry matter (ODM).

\begin{tabular}{|c|c|c|c|c|c|c|c|c|c|c|}
\hline \multirow{2}{*}{$\begin{array}{l}\text { Parameter } \\
\text { Reactor }\end{array}$} & \multirow{2}{*}{$\begin{array}{c}\text { Unit } \\
\text { triplicate-replicate }\end{array}$} & \multicolumn{3}{|c|}{ Control without Biochar } & \multicolumn{3}{|c|}{ 5\% Biochar Addition } & \multicolumn{3}{|c|}{ 10\% Biochar Addition } \\
\hline & & $0-1$ & $0-2$ & $0-3$ & $1-1$ & $1-2$ & $1-3$ & $2-1$ & $2-2$ & $2-3$ \\
\hline Biogas $_{\text {total }}$ & NL & 479.0 & 475.1 & 477.5 & 491.6 & 472.4 & 546.2 & 498.7 & 497.8 & 480.0 \\
\hline Biogas $_{\text {total }}$ & $\mathrm{NL} / \mathrm{kg}_{O D M}$ & 453.3 & 449.6 & 451.9 & 465.2 & 447.0 & 516.8 & 471.9 & 471.0 & 454.2 \\
\hline Mean change & $\%$ & \multicolumn{3}{|c|}{-} & \multicolumn{3}{|c|}{+5.5} & \multicolumn{3}{|c|}{+3.1} \\
\hline Biogas $_{\text {digestate }}$ & NL & 9.7 & 9.7 & 9.7 & 9.7 & 9.7 & 9.7 & 9.7 & 9.7 & 9.7 \\
\hline Biogas $_{\text {percolate }}$ & NL & 3.4 & 3.4 & 3.4 & 3.4 & 3.4 & 3.4 & 3.4 & 3.4 & 3.4 \\
\hline Biogas $_{\text {bio-waste }}$ & NL & 465.9 & 462.0 & 464.5 & 478.5 & 459.3 & 533.1 & 485.6 & 484.7 & 466.9 \\
\hline Biogas $_{\text {bio-waste }}$ & $\mathrm{NL} / \mathrm{kg}_{O D M}$ & 514.0 & 509.7 & 512.4 & 527.9 & 506.7 & 588.1 & 535.7 & 534.7 & 515.1 \\
\hline Mean change & $\%$ & \multicolumn{3}{|c|}{-} & \multicolumn{3}{|c|}{+5.6} & \multicolumn{3}{|c|}{+3.2} \\
\hline Methane $_{\text {total }}$ & NL & 260.7 & 257.8 & 258.3 & 264.4 & 256.0 & 295.7 & 269.4 & 270.7 & 259.9 \\
\hline Methane $_{\text {total }}$ & $\mathrm{NL} / \mathrm{kg}_{O D M}$ & 246.7 & 243.9 & 244.4 & 250.2 & 242.3 & 279.8 & 254.9 & 256.1 & 245.9 \\
\hline Mean change & $\%$ & \multicolumn{3}{|c|}{ - } & \multicolumn{3}{|c|}{+5.1} & \multicolumn{3}{|c|}{+3.0} \\
\hline
\end{tabular}

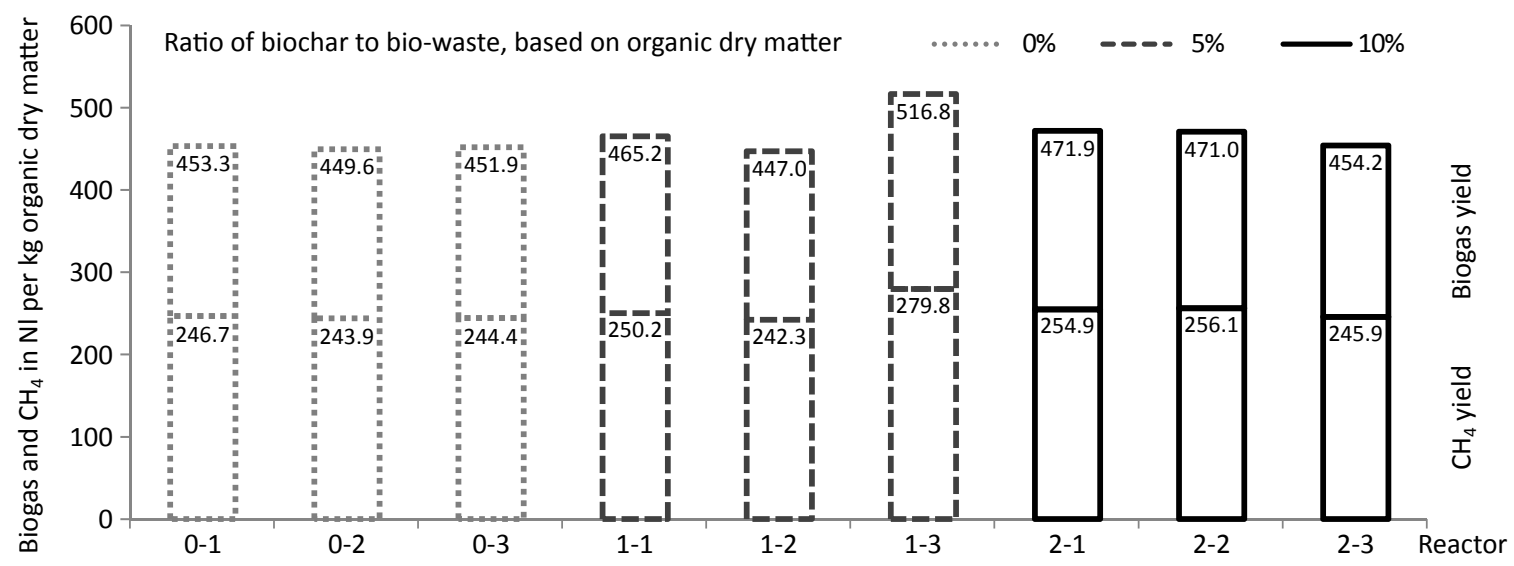

Figure 2. Biogas and methane $\left(\mathrm{CH}_{4}\right)$ yields for all reactors.

Table 1 provides also the biogas yield from bio-waste alone by subtracting the biogas potentials of digestate and percolate, which were determined separately. The result of the subtraction is then divided by the bio-waste ODM. Because the methane content of the percolate biogas was not determined, the specific methane yield for bio-waste could not be calculated. However, one can expect that the influence on the mean change of a triplicate would be low, similar to the biogas results $(+5.5 \%$ vs. $+5.6 \%$ and $+3.1 \%$ vs. $+3.2 \%)$.

Figure 2 visualizes the biogas yields per kg organic dry matter. It is easy to spot reactor 1-3 as the one with the highest yield. This is the reason why the triplicate with the $5 \%$ biochar addition (reactors 1-1, 1-2, and 1-3) has the highest mean yield in biogas and methane. Also, the relative standard deviation (coefficient of variation) within this triplicate is high $(7.7 \%)$, compared to the $10 \%$ biochar addition $(2.2 \%)$ and to the control $(0.6 \%)$. Nonetheless, the biogas yields of each reactor are quite similar. In addition, all reactors produced a biogas with a $\mathrm{CH}_{4}$-content of around $54 \%$.

Based on the resembling yields of the reactors it can be concluded that the trial successfully simulated the biogas plant in Erfurt. This is substantiated by correlating biogas yields (based on fresh matter (FM) bio-waste) between the control triplicate with $116 \mathrm{NL} / \mathrm{kg}_{F M}$ and the biogas plant with $85 \mathrm{NL} / \mathrm{kg}_{F M}$ [20], where stones and branches are not removed from the bio-waste.

The triplicates with a biochar addition of $5 \%_{O D M}$, respectively $10 \%_{O D M}$ show a yield increase compared to the control of around 5\%, respectively $3 \%$, both for biogas and methane. However, each triplicate has one reactor with very similar yields compared to the control. Therefore, the increased yields could also be attributed to the heterogeneity of the bio-waste. It can be concluded that the biochar did not inhibit the anaerobic digestion and possibly increased the gas yields marginally. 


\section{Discussion}

As mentioned in the introduction, prior trials with biochar in anaerobic digestion have resulted in various methane yield changes. Table 2 provides an overview about these trials and their key parameters. The trials are sorted chronologically, beginning with Kumar et al. (1987), followed by Ithapanya et al. (2012) and the others, and concluded with the trial presented in this paper. Because the publications by Ithapanya et al. do not contain any information about dry matter contents, the ratios of biochar to substrate are consistently based on fresh matter, including all digestate and added water. Standard deviations for the $\mathrm{CH}_{4}$ yield changes, or the necessary data to calculate them, are only published by Mumme et al. and are therefore not included in the table.

Table 2. Methane $\left(\mathrm{CH}_{4}\right)$ yield changes in prior and current investigations in regard to fresh matter (FM) ratios of biochar to substrate.

\begin{tabular}{|c|c|c|c|c|c|c|c|}
\hline Source & $\begin{array}{l}\text { Trial Type, } \\
\text { Condition, Duration }\end{array}$ & $\begin{array}{l}\text { Substrate } \\
\text { Composition }\end{array}$ & $\begin{array}{c}\text { Amount } \\
\mathrm{g}_{F M}\end{array}$ & $\#$ & $\begin{array}{l}\text { Origin of Added Biochar } \\
\text { or Hydrochar (HTC) }\end{array}$ & $\begin{array}{l}\text { Rate } \\
\%_{F M}\end{array}$ & $\underset{\%}{\mathrm{CH}_{4} \text { Yield }}$ \\
\hline \multirow{2}{*}{$\begin{array}{l}\text { Kumar } \\
\text { et al. [12] }\end{array}$} & $\begin{array}{l}\text { continuous flow }{ }^{2} \\
35^{\circ} \mathrm{C}, 40 \text { days }\end{array}$ & \multirow{2}{*}{$\begin{array}{l}\text { cow slurry } \\
\text { (8\% solids) }\end{array}$} & \multirow[t]{2}{*}{5000} & \multirow{2}{*}{$\begin{array}{l}2 \\
2\end{array}$} & \multirow[t]{2}{*}{ charcoal powder } & \multirow[t]{2}{*}{0.40} & $1+34.7$ \\
\hline & $\begin{array}{l}\text { batch, glas bottles } \\
35^{\circ} \mathrm{C}, 40 \text { days }\end{array}$ & & & & & & ${ }^{1}+17.4$ \\
\hline \multirow{2}{*}{$\begin{array}{l}\text { Ithapanya } \\
\text { et al. [13] }\end{array}$} & batch, glass bottles & cattle manure & 283 & 4 & \multirow{2}{*}{ rice husks $\left(900-1000^{\circ} \mathrm{C}\right)$} & 0.05 & +28.9 \\
\hline & $35^{\circ} \mathrm{C}, 30$ days & water & 905 & 4 & & $\overline{0.15}$ & +30.8 \\
\hline $\begin{array}{l}\text { Ithapanya } \\
\text { et al. [14] }\end{array}$ & $\begin{array}{l}\text { continuous flow }{ }^{2} \\
25-30{ }^{\circ} \mathrm{C}, 20 \text { days }\end{array}$ & $\begin{array}{l}\text { cattle manure } \\
\text { water }\end{array}$ & $\begin{array}{l}3000 \\
9000\end{array}$ & 4 & rice husks $\left(900-1000{ }^{\circ} \mathrm{C}\right)$ & 0.05 & -0.9 \\
\hline $\begin{array}{l}\text { Rödger } \\
\text { et al. [15] }\end{array}$ & $\begin{array}{l}\text { batch, HDPE barrels } \\
37^{\circ} \mathrm{C}, 40 \text { days }^{3}\end{array}$ & $\begin{array}{l}\text { corn silage } \\
\text { digestate }\end{array}$ & $\begin{array}{c}366 \\
20,000\end{array}$ & 3 & woodchips $\left(550^{\circ} \mathrm{C}\right)$ & 2.46 & +21.7 \\
\hline \multirow{2}{*}{$\begin{array}{l}\text { Mumme } \\
\text { et al. [16] }\end{array}$} & batch, glass syringes & \multirow[t]{2}{*}{ digestate } & \multirow[t]{2}{*}{30} & 3 & paper sludge+wheat $\left(550^{\circ} \mathrm{C}\right)$ & \multirow[t]{2}{*}{6.67} & -8.5 \\
\hline & $42{ }^{\circ} \mathrm{C}, 63$ days & & & 3 & straw digestate $\left(\mathrm{HTC} 230^{\circ} \mathrm{C}\right)$ & & +31.7 \\
\hline \multirow{2}{*}{$\begin{array}{l}\text { Velghe } \\
\text { OWS [17] }\end{array}$} & batch, glas reactors & $\begin{array}{l}\text { cauliflower }^{4} \\
\text { digestate }\end{array}$ & $\begin{array}{c}100 \\
1000\end{array}$ & 2 & \multirow{2}{*}{ holm oak residues $\left(650^{\circ} \mathrm{C}\right)$} & \multirow[t]{2}{*}{0.18} & +1.1 \\
\hline & $52{ }^{\circ} \mathrm{C}, 14$ days & $\begin{array}{l}\text { leek }{ }^{4} \\
\text { digestate }\end{array}$ & $\begin{array}{c}100 \\
1000\end{array}$ & 2 & & & +0.1 \\
\hline \multirow{2}{*}{$\begin{array}{l}\text { by the } \\
\text { authors }\end{array}$} & batch, steel reactors & bio-waste & 4000 & 3 & \multirow[t]{2}{*}{ holm oak residues $\left(650^{\circ} \mathrm{C}\right)$} & 0.83 & +5.1 \\
\hline & $40^{\circ} \mathrm{C}, 30$ days & digest.+percol. & 4000 & 3 & & 1.65 & +3.0 \\
\hline
\end{tabular}

Notes: ${ }^{1}$ refers to biogas yield only; ${ }^{2}$ number of days equals the retention time, not the trial duration;

${ }^{3}$ trials were continued till day 91 , which reduced the $\mathrm{CH}_{4}$ yield to $+8.9 \%{ }^{4}$ mixed with corn stover;

\# number of replicates; $F M$ fresh matter.

What strikes first in regard to the trials is the variety of substrates and biochars and their ratios. This variety is complemented by different trial conditions. Although this makes a comparative analysis nearly impossible, all these trials add important aspects to a bigger picture.

It starts with the question why it took 25 years after Kumar et al. to make new investigations on this topic. Ithapanya et al. answer this indirectly by asking if it could make sense to extract the biochar from the digestate to re-use it. The rationale behind this can have two reasons. First, biochar is a commodity with a price. Even if green waste for free could be used to produce the biochar, which would be the case at German bio-waste-to-biogas plants, the costs for the production [5] would still put a price tag on it. Therefore, the increased methane yields would need to be high enough to compensate for the biochar price. With the favorable EEG feed-in tariff for electricity from bio-waste this might be achievable, but that was probably not the case in the economic framework of Kumar et al. and Ithapanya et al. Second, the cascade model for biochar mentioned by Rödger et al. was probably not considered yet. Recognizing also the possible benefits during the post-composting of the biochar-enhanced digestate, and later the benefits by the biochar-compost in the soil, could lead to a sum much higher than the cost of the biochar. 
The substrate compositions of Kumar et al. and Ithapanya et al. probably reveal a major principle of biochar in anaerobic digestion. Cow slurry and cattle manure can be rich in nitrogen and this can lead to ammonia inhibition. While an adjusted biocenosis, e.g., in digestate, can handle high ammonia loads [21,22], these trials were done with fresh substrate and water only. It seems that the biochar helped to overcome these poor initial conditions.

The mechanisms behind this could be in providing favorable conditions for the biocenosis, either by acting as buffer for inhibitory substances, or by delivering micro-nutrients, or by creating habitats. Ithapanya et al. suspect the formation of bio-films, which could more easily overcome certain inhibitory effects. This point correlates with the higher number of microorganisms reported by Kumar et al. and Mumme et al. In regard to these two findings, it could be argued that the low temperatures during the second trial by Ithapanya et al. led to conditions where these mechanisms could not work, resulting in no significant yield change.

The hydrochar, produced by hydrothermal carbonization (HTC), in the trial by Mumme et al. led to a higher yield because of its high labile carbon content, which was digested. Why the biochar decreased the yield by $8.5 \%$ is not clear. However, this trial stands out with its very low amount of substrate and a very high ratio of biochar. While it is important to recognize this negative result, its relevance for the whole picture should not be overrated. In addition, this yield change falls within the standard deviation of the control and is therefore inconclusive.

The marginal-and likewise inconclusive-yield raises in the trials by Velghe and by the authors could be the result of a nearly optimal process. Both trials used digestate from industrial bio-waste-to-biogas plants, which provided an ideal biocenosis from the start. In addition, the solid-state fermentation by the authors provided enough stable surfaces for bio-films. In sum, it may simply be that there were no inhibitory effects that could be mitigated by biochar.

In conclusion, the mechanisms that are responsible for higher methane yields through biochar addition are not fully understood. However, it was shown that biochar can be a useful additive to optimize biogas production in certain conditions. Based on a cascade approach this could yield numerous benefits. Further investigations in this direction, especially in regards to alleviating suboptimal process conditions, seem promising.

\section{Materials and Methods}

The trial is a mesophilic $\left(40^{\circ} \mathrm{C}\right)$ solid-state (batch) fermentation with percolation, which simulates an existing large-scale biogas operation, a BEKON facility established in Erfurt, Germany in 2008. This facility has an annual capacity of $18,200 \mathrm{Mg}$ bio-waste and converts the $1,547,000 \mathrm{~m}^{3}$ biogas into $3,993,900 \mathrm{kWh}$ electricity [20].

\subsection{Trial Setup}

The trial setup outlined in Figures 3 and 4 includes eleven reactors. They are made of steel, with a plastic bottom and cover plate. Each has an internal volume of $18 \mathrm{~L}$. The substrate in the reactor is held in place by two perforated steel plates with $5 \mathrm{~mm}$ holes. The percolate fluid dashes against the top plate and spreads all over it, allowing a complete distribution over the full area. At the bottom, the perforated plate prevents the escape of larger particles, which could block the hose connectors.

Two of the eleven reactors are only used for the gas potential test of the digestate. The remaining nine reactors are connected to percolation tanks as illustrated in Figure 4. The percolate hoses are made of polyamide and have an outside diameter of $12 \mathrm{~mm}$. In order to avoid gas pressure buildups from the speed difference between percolate pump and the percolation within the substrate, pressure compensation hoses connect the percolate tanks with top and bottom of the reactors. These hoses are made of polyamide as well and have an outside diameter of $8 \mathrm{~mm}$. The percolate pumps (Elegant-Inline by Comet) have a delivery head of $5.5 \mathrm{~m}$ and are installed at the very bottom of the percolate circulation to avoid dry running. All pumps are activated by a central, programmable control relay. 




(a)

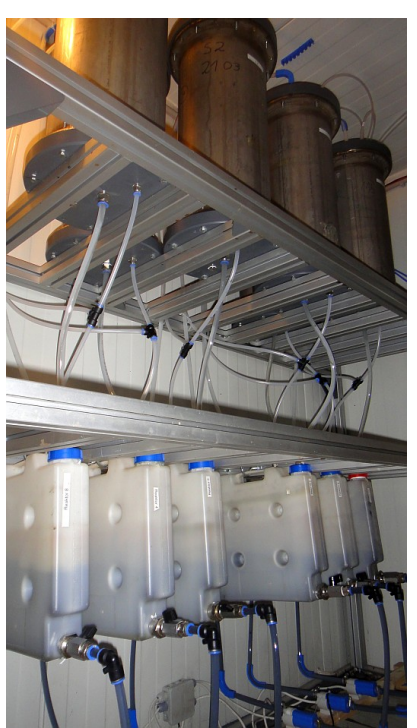

(b)

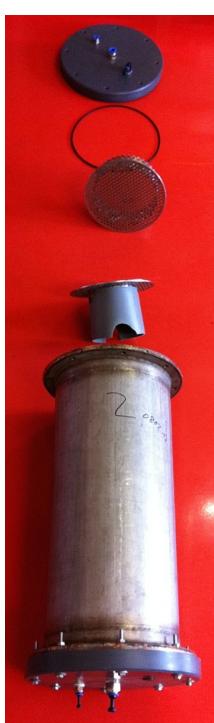

(c)

Figure 3. Test setup with (a) gas meters and gas storage bags in front of the climate chamber; (b) reactors and percolation tanks in the climate chamber; (c) components of a single reactor.



Figure 4. Scheme of the test setup for one reactor including gas collection and metering.

With a constant temperature of $40^{\circ} \mathrm{C}$ the biogas leaves the climate chamber via the gas hoses (polyamide, $8 \mathrm{~mm}$ ). At a room temperature between 20 and $25^{\circ} \mathrm{C}$ emerging condensate is collected in the condensate traps. They are simple end fittings which can shortly be opened to release the condensate from time to time. The biogas then passes magnet valves, which are closed by the control relay when the percolate pumps are active and then for one more minute. This eliminates any possible back flow from the gas bags during percolation, although the pressure compensation hoses in the climate chamber reduce this possibility already.

The used gas meters (TG05/5 by Dr.-Ing. RITTER Apparatebau GmbH \& Co. KG) can only withstand an excess pressure of 50 mbar. In case the $20 \mathrm{~L}$ gas bags (by RITTER as well) are not exchanged in time before they are full, the meters could be damaged. Therefore, a fermentation lock is installed in front of each meter. The glass locks are standard wine making equipment, although they are filled with sealing liquid (Silox by RITTER) to prevent gas diffusion during normal operation. In case of an overfull gas bag, the lock releases biogas before the excess pressure reaches critical levels. 
For the gas quality a gas analyzer (by Awite Biotechnologie $\mathrm{GmbH}$ ) is used, which is frequently calibrated. The analyzer provides measurements of methane, carbon dioxide, and oxygen in percentage. For each measurement, the gas bags have to be disconnected from the trial installation and connected to the analyzer. At the end of the analysis the remaining gas in the bags gets exhausted by an electric pump and the empty bags get reconnected to the installation.

\subsection{Trial Substrates}

To simulate the operations of the industrial biogas plant, original substrate from it was used in the trials. This includes bio-waste (OFMSW) as main substrate, digestate as inoculum, and percolate for the percolation.

The used biochar was produced from a clean forestry wood residue (Holm Oak) at $650{ }^{\circ} \mathrm{C}$ using a commercial mono retort reactor (by Proininso S.A.). It is the reference biochar of the FP7 Fertiplus project (2011-2015), which has also been used in field trials and composting experiments. Table 3 provides the results of the analysis, done by the University of Leeds. It has to be stressed that the analyzed parameters can vary from batch to batch. For example, Table 4 (Reactor contents) reveals that the organic dry matter of the batch used in this trial is 8.7 percentage points lower than of the batch analyzed in Table 3.

Table 3. Biochar properties [23] and thresholds of the European Biochar Certificate (EBC) [24].

\begin{tabular}{|c|c|c|c|c|c|c|c|c|c|}
\hline \multirow{2}{*}{ Parameter } & \multirow{2}{*}{ Unit } & \multirow{2}{*}{ Biochar } & \multicolumn{2}{|r|}{ EBC } & \multirow{2}{*}{ Parameter } & \multirow{2}{*}{ Unit } & \multirow{2}{*}{ Biochar } & \multicolumn{2}{|c|}{ EBC } \\
\hline & & & Basic & Premium & & & & Basic & Premium \\
\hline \multicolumn{3}{|c|}{ Ultimate analysis (on dry ash-free basis) } & & & \multicolumn{5}{|c|}{ Micro-nutrients } \\
\hline $\mathrm{C}$ & $\%$ & 76.5 & $>50$ & $>50$ & $\mathrm{Mn}$ & $\mathrm{mg} / \mathrm{kg}$ & 426 & & \\
\hline $\mathrm{H}$ & $\%$ & 1.4 & & & $\mathrm{Fe}$ & $\mathrm{mg} / \mathrm{kg}$ & 415 & & \\
\hline $\mathrm{O}$ & $\%$ & 7.0 & & & $\mathrm{Zn}$ & $\mathrm{mg} / \mathrm{kg}$ & 56 & $<400$ & $<400$ \\
\hline $\mathrm{N}$ & $\%$ & 0.8 & & & B & $\mathrm{mg} / \mathrm{kg}$ & 32 & & \\
\hline $\mathrm{S}$ & $\%$ & 0.0 & & & $\mathrm{Cu}$ & $\mathrm{mg} / \mathrm{kg}$ & 11 & $<100$ & $<100$ \\
\hline $\mathrm{H} / \mathrm{C}$ & - & 0.2 & $<0.7$ & $<0.7$ & Mo & $\mathrm{mg} / \mathrm{kg}$ & $<0.5$ & & \\
\hline $\mathrm{O} / \mathrm{C}$ & - & 0.1 & $<0.4$ & $<0.4$ & \multicolumn{5}{|c|}{ Potentially toxic heavy metals } \\
\hline Proximate analysis & & & & & $\overline{\mathrm{Al}}$ & $\mathrm{mg} / \mathrm{kg}$ & 540 & & \\
\hline Moisture content & $\%$ & 15.2 & & & $\mathrm{~V}$ & $\mathrm{mg} / \mathrm{kg}$ & 44 & & \\
\hline Ash content & $\%$ & 14.3 & & & $\mathrm{Tl}$ & $\mathrm{mg} / \mathrm{kg}$ & 12 & & \\
\hline Organic dry matter & $\%$ & 85.7 & & & $\mathrm{Ni}$ & $\mathrm{mg} / \mathrm{kg}$ & 11 & $<50$ & $<30$ \\
\hline Volatile matter & $\%$ & 11.8 & & & $\mathrm{Ti}$ & $\mathrm{mg} / \mathrm{kg}$ & 8 & & \\
\hline $\mathrm{pH}$ & - & 10.3 & & & $\mathrm{Cr}$ & $\mathrm{mg} / \mathrm{kg}$ & 5 & $<90$ & $<80$ \\
\hline Macro-nutrients & & & & & $\mathrm{Pb}$ & $\mathrm{mg} / \mathrm{kg}$ & 2 & $<150$ & $<120$ \\
\hline $\mathrm{P}$ & $\%$ & 0.2 & & & $\mathrm{Cd}$ & $\mathrm{mg} / \mathrm{kg}$ & $<0.5$ & $<1.5$ & $<1$ \\
\hline $\mathrm{K}$ & $\%$ & 0.6 & & & $\mathrm{Sb}$ & $\mathrm{mg} / \mathrm{kg}$ & $<0.1$ & & \\
\hline $\mathrm{Ca}$ & $\%$ & 5.0 & & & $\mathrm{Be}$ & $\mathrm{mg} / \mathrm{kg}$ & $<0.1$ & & \\
\hline $\mathrm{Mg}$ & $\%$ & 0.3 & & & \multicolumn{5}{|c|}{ Sum of 16 Polycyclic Aromatic Hydrocarbons } \\
\hline $\mathrm{Na}$ & $\%$ & 0.0 & & & $\overline{\mathrm{PAH}}$ & $\mathrm{mg} / \mathrm{kg}$ & 0.24 & $<12$ & $<4$ \\
\hline
\end{tabular}

Table 4. Substrate contents for one reactor.

\begin{tabular}{lccccc}
\hline Parameter & Unit & Bio-Waste & Digestate & Percolate & Biochar \\
\hline Fresh matter & $\mathrm{g}$ & 4000.0 & 1000.0 & 3000.0 & $0 / 66.0 / 132.0$ \\
Dry matter & $\mathrm{g}$ & 1432.0 & 296.0 & 60.0 & $0 / 60.7 / 121.3$ \\
Organic dry matter & $\mathrm{g}$ & 906.5 & 126.1 & 24.3 & $0 / 46.7 / 93.4$ \\
Dry matter (DM) & $\%$ & 35.8 & 29.6 & 2.0 & 91.9 \\
Organic dry matter & $\%_{D M}$ & 63.3 & 42.6 & 40.5 & 77.0 \\
\hline
\end{tabular}

The analysis of the biochar was done following the recommended analytical methodologies by the International Biochar Initiative (IBI). To set the values in context, the respective thresholds for the voluntary European Biochar Certificate (EBC) are added as well. All physical and chemical parameters of the biochar are well within the limits of both EBC quality levels, basic and premium.

The substrate amounts per reactor are specified in Table 4, including the added amounts of biochar. The three controls are without biochar, while three other reactors receive $66 \mathrm{~g}$, which is around $5 \%$ 
of the bio-waste, based on organic dry matter. Another three reactors receive the double amount, resulting in a $10 \%$ ratio. The ratio of bio-waste to digestate, 4 to 1 based on fresh matter, corresponds to the industrial operation. The amount of the percolate was chosen to allow a full percolation cycle $(1 \mathrm{~L})$ without draining the percolate tank. Since all triplicates received the identical amount of substrates, this allows a direct comparison on the effect of biochar on the biogas yield.

The dry matter contents in Table 4 were determined according to DIN EN 14346. For each substrate two samples were analyzed, except for the bio-waste for which four samples were analyzed because of its high heterogeneity. The organic dry matter, respectively the volatile solids were determined according to DIN EN 15169. From each dry matter sample two samples were analyzed. The percentage values in the table are averages from these analyses.

\subsection{Trial Execution}

Before the actual trial a pre-trial was undertaken to identify weak spots of the setup. Because of several interruptions during this pre-trial the recorded data was not used for this paper, even though similar yield increases with biochar could be observed.

Some minor problems with leaking reactors, tanks and hose connectors were quickly identified and solved. A greater challenge posed the percolation cycle. It was planned to use nozzles which spray the percolate evenly onto the substrate. However, they were all clogged with solids after one or two days. This led to the solution with the perforated steel plate, were the percolate dashes against. The necessary operation time $(30 \mathrm{~s})$ for one percolation cycle $(1 \mathrm{~L})$ was determined by testing the throughput per time. Since all pumps have the same discharge and are connected by the same length of hoses, their operation time is identical. The percolation regime is based on the industrial operation, though not identical. It starts with 19 percolation cycles on day one, is reduced to 12 per day on day two and three, then further reduced to 6 per day on day four and five, and finally continues with 3 cycles from day six until the last day of the trial.

Another major problem identified in the pre-trial was the clogging of the pumps. This happened frequently when percolation cycles were reduced to three times a day. While with a longer operation time each pump could be unclogged, this clearly threatened the accuracy of the percolation regime. The problem was solved by adding a short pump interval (1s) to each full hour and two intervals before a percolation. This is short enough to prevent any percolate to enter the reactors, but long enough to prevent any sedimentation of solids, which was the likely source of the clogging.

The actual trial is done with three simultaneous triplicates $(3 \times 3$ reactors), one triplicate as the control and the others with two different supplement ratios of biochar. The amount of the reactor contents was already provided in Table 4. Parallel to the trial, two additional reactors without percolation are filled with $5 \mathrm{~kg}$ digestate to determine its biogas potential. The potential of the percolate is determined with two $800 \mathrm{~g}$ samples in glass bottles. They are shaken once a day and the gas production is recorded daily for the full duration of the trial. Because much less gas is produced than in the reactors, smaller gas meters are used (MGC-1 PMMA by RITTER).

The trial begins with the preparation of the substrates. Except for the biochar which was in storage for some weeks, all other substrates are transported from the industrial biogas plant to the laboratory a few days earlier. Digestate and percolate are stored at $40{ }^{\circ} \mathrm{C}$ to keep the biocenosis intact. The bio-waste is stored at $4{ }^{\circ} \mathrm{C}$ to reduce decomposition. Prior to mixing the substrates, the digestate is slowly stirred to homogenize it. This is also done for the percolate before pouring it into the reactors. The bio-waste is only cleared of rocks, branches, and larger plastic parts, but not shredded. This is done to simulate the industrial conditions, but it also reduces the chances of clogging in the reactor during percolation. Clogging occurred once in the pre-trial, which was quickly identified because the percolate tank was drained. A short but intense shake unclogged the reactor.

Bio-waste, digestate, and biochar are mixed together manually and then put into the reactors. The perforated steel plate is based on top of the substrate. Then the percolate is slowly poured onto the plate, initiating the first percolation cycle. The cover plate of the reactor is then added and screwed 
tight. When all hoses are connected to the cover plate the reactor system is in operation. Like in the industrial biogas plant, the batch process starts in ambient air and changes slowly to a carbon dioxide-methane atmosphere.

The following 30 days include mainly gas analyses, data recording, and frequent controls of the percolation cycles. The trial is terminated at day 31, although only data until day 30 is analyzed. The termination criterion according to VDI 4630 , daily gas production of less than $1 \%$ of the accumulated amount, was already fulfilled then. The removal of the substrates from the reactors shows that all contents are completely wet and there are no dry zones. While this does not reveal much about the quality of the percolation, it confirms that all substrates could take part in the anaerobic digestion.

Acknowledgments: This study was undertaken within the project FERTIPLUS (Grant Agreement No. 289853), which is co-funded by the European Commission, Directorate General for Research \& Innovation, within the 7th Framework Programme of RTD, Theme 2-Biotechnologies, Agriculture \& Food. The views and opinions expressed in this paper are purely those of the authors and may not in any circumstances be regarded as stating an official position of the European Commission. The authors thank the public utility company Bioverwertung \& Recycling $\mathrm{GmbH}$ for the provision of bio-waste, percolate, and digestate and for the insight into their operations.

Author Contributions: Daniel Meyer-Kohlstock and Thomas Haupt conceived and designed the experiments; Erik Heldt, Nils Heldt and Daniel Meyer-Kohlstock performed the experiments and analyzed the data; Eckhard Kraft contributed materials, analysis tools, and good advice; Daniel Meyer-Kohlstock wrote the paper.

Conflicts of Interest: The authors declare no conflict of interest.

\section{Abbreviations}

The following abbreviations are used in this manuscript:

$\begin{array}{ll}\text { DM } & \text { Dry matter } \\ \text { EBC } & \text { European Biochar Certificate } \\ \text { EEG } & \text { German Renewable Energy Act } \\ \text { FM } & \text { Fresh matter } \\ \text { FP7 } & \text { 7th Framework Programme } \\ \text { HDPE } & \text { High density polyethylene } \\ \text { HTC } & \text { Hydrothermal carbonization } \\ \text { IBI } & \text { International Biochar Initiative } \\ \text { MDPI } & \text { Multidisciplinary Digital Publishing Institute } \\ \text { ODM } & \text { Organic dry matter } \\ \text { OFMSW } & \text { Organic fraction of municipal solid waste }\end{array}$

\section{References}

1. Fachverband Biogas e.V. Biogas Segment Statistics 2014/2015. German Biogas Association: Freising, Germany, 2015. Available online: http://www.biogas.org/edcom/webfvb.nsf/id/DE_Branchenzahlen (accessed on 10 January 2016).

2. BNetzA. List of Power Plants - Renewables on 31 December 2014. Bundesnetzagentur (Federal Network Agency for Electricity, Gas, Telecommunications, Posts and Railway): Bonn, Germany, 2015. Available online: http://www.bundesnetzagentur.de/cln_1421/EN/Areas/Energy/Companies/SecurityOfSupply/ GeneratingCapacity/PowerPlantList/PubliPowerPlantList_node.html (accessed on 10 January 2016).

3. Schmidt, H.P. 55 Uses of Biochar. Ithaka J. 2012, 1, 286-289.

4. Yoshizawa, S.; Tanaka, S.; Ohata, M.; Mineki, S.; Goto, S.; Fujioka, K.; Kokubun, T. Composting of food garbage and livestock waste containing biomass charcoal. In Proceedings of the International Conference and Natural Resources and Environmental Management, Kuching, Sarawak, 28-29 November 2005; Volume 8, p. 2011. 
5. Dunst, G. Die erste abfallrechtlich bewilligte Pflanzenkohle-Produktionsanlage Europas (The first legally approved waste biochar production facility in Europe). Müll und Abfall 2013, 12, 661-664.

6. Vandecasteele, B.; Sinicco, T.; D’Hose, T.; Nest, T.V.; Mondini, C. Biochar amendment before or after composting affects compost quality and $\mathrm{N}$ losses, but not $\mathrm{P}$ plant uptake. J. Environ. Manag. 2016, 168, 200-209.

7. Sánchez-García, M.; Alburquerque, J.A.; Sánchez-Monedero, M.A.; Roig, A.; Cayuela, M.L. Biochar accelerates organic matter degradation and enhances $\mathrm{N}$ mineralisation during composting of poultry manure without a relevant impact on gas emissions. Bioresour. Technol. 2015, 192, 272-279.

8. Huang, X.-D.; Xue, D. Effects of bamboo biochar addition on temperature rising, dehydration and nitrogen loss during pig manure composting. Yingyong Shengtai Xuebao 2014, 25, 1057-1062.

9. Jindo, K.; Suto, K.; Matsumoto, K.; García, C.; Sonoki, T.; Sánchez-Monedero, M.A. Chemical and biochemical characterisation of biochar-blended composts prepared from poultry manure. Bioresour. Technol. 2012, 110, 396-404.

10. Steiner, C.; Das, K.C.; Melear, N.; Lakly, D. Reducing nitrogen loss during poultry litter composting using biochar. J. Environ. Qual. 2010, 39, 1236-1242.

11. Yoshizawa, S.; Tanaka, S.; Ohata, M.; Mineki, S.; Goto, S.; Fujioka, K.; Kokubun, T. Promotion effect of various charcoals on the proliferation of composting microorganisms. TANSO 2006, 224, 261-265.

12. Kumar, S.; Jain, M.C.; Chhonkar, P.K. A note on stimulation of biogas production from cattle dung by addition of charcoal. Biol. Wastes 1987, 20, 209-215.

13. Inthapanya, S.; Preston, T.R.; Leng, R.A. Biochar increases biogas production in a batch digester charged with cattle manure. Livest. Res. Rural Dev. 2012, 24. Available online: http://www.lrrd.org/lrrd24/12/sang 24212.htm (accessed on 11 January 2016).

14. Inthapanya, S.; Preston, T.R. Biochar marginally increases biogas production but decreases methane content of the gas in continuous-flow biodigesters charged with cattle manure. Livest. Res. Rural Dev. 2013, 25; Available online: http://lrrd.cipav.org.co/lrrd25/11/sang25189.htm (accessed on 11 January 2016).

15. Rödger, J.-M.; Ganagin, W.; Krieg, A.; Roth, C.; Loewen, A. Steigerung des Biogasertrages durch die Zugabe von Pflanzenkohle. Müll und Abfall 2013, 9, 476-481.

16. Mumme, J.; Srocke, F.; Heeg, K.; Werner, M. Use of biochars in anaerobic digestion. Bioresour. Technol. 2014, 164, 189-197.

17. Velghe, F. Organic Waste Systems (OWS nv). Personal communication, Gent, Belgium, 2015.

18. Erneuerbare-Energien-Gesetz. Erneuerbare-Energien-Gesetz-EEG 2014 (Renewable Energy Act 2014) §45 Vergärung von Bioabfällen (Anaerobic digestion of bio-waste); Federal Republic of Germany: Germany, 2014.

19. Kern, M.; Raussen, T. Biogas-Atlas 2014/2015-Anlagenhandbuch der Vergärung biogener Abfälle in Deutschland und Europa; Witzenhausen-Institut: Witzenhausen, Germany, 2014; pp. 19-26.

20. Stadtwerke Erfurt Gruppe-Bioabfallverwertung (Public utility company Erfurt-Bio-waste utilisation). Available online: https://www.stadtwerke-erfurt.de/pb/site/swegruppe/node/19546/Lde/index.html (accessed on 9 January 2016).

21. Yenigün, O.; Demirel, B. Ammonia inhibition in anaerobic digestion: A review. Process Biochem. 2013, 48, 901-911.

22. Rajagopal, R.; Massé, D.I.; Singh, G. A critical review on inhibition of anaerobic digestion process by excess ammonia. Bioresour. Technol. 2013, 143, 632-641.

23. Ross, A. FERTIPLUS Deliverable 3.5-Data set on properties and composition of biochar (obtained from Surjit Singh in August 2013)-Revision 4.0 (Final Version) of 29 August 2015. unpublished.

24. EBC. European Biochar Certificate-Guidelines for a Sustainable Production of Biochar. European Biochar Foundation (EBC), Arbaz, Switzerland. Version 6.1 of 19 June 2015. Available online: http://www. european-biochar.org/en/downloadthecertificate (accessed on 20 January 2016).

(C) 2016 by the authors; licensee MDPI, Basel, Switzerland. This article is an open access article distributed under the terms and conditions of the Creative Commons by Attribution (CC-BY) license (http://creativecommons.org/licenses/by/4.0/). 